
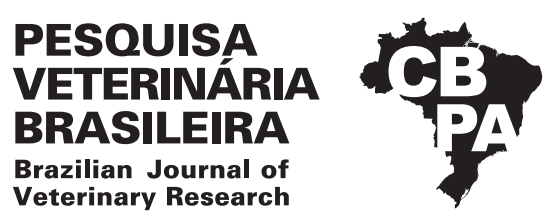

Pesq. Vet. Bras. 39(7):549-560, July 2019

DOI: 10.1590/1678-6160-PVB-6160

ISSN 0100-736X (Print)

ISSN 1678-5150 (Online)

\title{
Development of the urinary system in guinea pig females (Cavia porcellus) ${ }^{1}$
}

\author{
Amilton C. Santos ${ }^{2}$ (D), Antônio F.S. Lisboa-Neto² Ingrid K.L. Silva ${ }^{3}$, Helton C.S. Pereira², \\ Júlia M. Silveira ${ }^{2}$, Erick E. Silveira ${ }^{2}$, Bruno G. Vasconcelos ${ }^{4}$ and Antônio C. Assis-Neto ${ }^{2 *}$
}

\begin{abstract}
Santos A.C., Lisboa-Neto A.F.S., Silva I.K.L., Pereira H.C.S., Silveira J.M., Silveira E.E., Vasconcelos B.G. \& Assis-Neto A.C. 2019. Development of the urinary system in guinea pig females (Cavia porcellus). Pesquisa Veterinária Brasileira 39(7):549-560. Faculdade de Medicina Veterinária e Zootecnia, Universidade de São Paulo, Rua Prof. Orlando Marques de Paiva 87, São Paulo, SP 05508-270, Brazil. E-mail: antonioassis@usp.br

Guinea pigs are animal models widely used in research related to developmental biology. The objective of this work was to demonstrate the process of formation and differentiation of urinary organs in females of the species in the prenatal period. Four females were used at $25,30,45$ and $>65$ DG (days of gestation). The animals were dissected, and then macroscopic and microscopic descriptions of the urinary organs were performed. At 25 DG metanephros were present in the urogenital crest into the abdominal cavity. Collecting ducts and glomerular precursor cells could be visualized. After this period, metanephros underwent microstructural modifications to form the kidneys at the end of the prenatal period. After $30 \mathrm{DG}$, the renal parenchyma already had a cortex, where the glomerulus and proximal convoluted tubules were present; and the medulla, where distal convoluted tubules, collecting ducts, and pelvis were present. The pelvis of each kidney was drained by the ureters. The ureters also underwent tissue differentiation to be differentiated (mucosa with transitional epithelium and lamina propria of connective tissue, muscular, and adventitia) at the end of the prenatal period. The urinary vesicle also underwent tissue changes to form the tunics similar to those found in the ureters, with emphasis on the greater volume of the muscular tunica and the lamina propria that constituted the submucosa in this organ. The pelvic urethra was evidenced by a mucosa lined by transitional epithelium, submucosa, muscular and adventitia. Finally, a partial clitoral urethra and a urethral meatus in the prepuce of the clitoris were also evidenced. The urethral channel began to form with the emergence of the urethral plate and the urethral groove at $30 \mathrm{DG}$ and thereafter with the fusion of the urethral folds to form a partially channeled urethra in the clitoris. A urethral meatus was observed in the most distal portion of the clitoral tissue, formed by the fusion of the prepuce. It is concluded that the urinary organs of guinea pig have similar development to that described in domestic animals, except for the partial clitoral urethra and evident urethral meatus.
\end{abstract}

INDEX TERMS: Urinary system, guinea pig, Cavia porcellus, embryology, experimental models, metanephros, rodents.

\footnotetext{
${ }^{1}$ Received on January 17, 2019.

Accepted for publication on February 19, 2019.

${ }^{2}$ Faculdade de Medicina Veterinária e Zootecnia, Universidade de São Paulo (USP), Rua Prof. Dr. Orlando Marques de Paiva 87, São Paulo, SP 05508-270, Brazil. E-mails: amiltonsantoss@usp.br, lisboaneto@usp.br, jmsyep@gmail.com, heltoncarlossp@hotmail.com, erickanatovet@gmail. com; *Corresponding author: antonioassis@usp.br

${ }^{3}$ Centro Universitário Fundação de Ensino Octávio Bastos (UniFEOB), Av. Dr. Octávio Bastos, São João da Boa Vista, SP 13870-000, Brazil. E-mail: ingrid-kester@hotmail.com

${ }^{4}$ Universidade Federal dos Vales Jequitinhonha e Mucuri, Av. Vereador João Narciso 1380, Cachoeira, Unaí, MG 38610-000, Brazil. E-mail: vasconcelosufvjm@gmail.com
}

RESUMO.- [Desenvolvimento do sistema urinário em
fêmeas de porquinhos-da-índia (Cavia porcellus).]
Os porquinhos-da-índia são modelos animais amplamente
utilizados em pesquisas relacionadas a biologia do
desenvolvimento. O objetivo deste trabalho foi demonstrar
o processo de formação e diferenciação dos órgãos urinários
em fêmeas da espécie no período pré-natal. Foram utilizadas
quatro fêmeas aos $25,30,45$ e > 65 DG (dias de gestação).
Os animais foram dissecados e então, realizaram-se descrições
macroscópicas e microscópicas dos órgãos urinários. Aos 25 DG
os metanefros estavam presentes na crista urogenital da 
cavidade abdominal. Podiam ser visualizados ductos coletores e células precursoras glomerulares. Após este período, os metanefros sofreram modificações microestruturais para formar os rins ao final do período pré-natal. Após os 30 DG, o parênquima renal já apresentava um córtex, onde estavam presentes os glomérulos e túbulos convolutos proximais, e a medula onde estavam presentes túbulos convolutos distais, ductos coletores e a pelve. A pelve de cada rim era drenada pelos ureteres. Os ureteres também sofreram diferenciação tecidual para estarem com suas túnicas diferenciadas (mucosa com epitélio de transição e lâmina própria de tecido conjuntivo; muscular; e, adventícia) ao final do período pré-natal. A vesícula urinária também passou por modificações teciduais para formar as túnicas semelhantes as dos ureteres, com destaque para o maior volume da túnica muscular e a lâmina própria que constituiu a submucosa neste órgão. Uma uretra pélvica foi evidenciada por uma mucosa revestida por epitélio de transição, submucosa, muscular e adventícia. Por último, uma uretra parcialmente clitoriana e um meato uretral no prepúcio do clitóris também foi evidenciado. 0 canal uretral começou a se formar com o aparecimento da placa uretral e do sulco uretral aos 30 DG e posteriormente com a fusão das pregas uretrais para formar uma uretra parcialmente canalizada no clitóris. Observou-se um meato uretral na porção mais distal do tecido clitoriano, formado pela fusão do prepúcio. Conclui-se que os órgãos urinários do porquinho-da-índia possuem desenvolvimento semelhante ao descrito em animais domésticos, com exceção da uretra parcialmente clitoriana e do meato uretral evidente.

TERMOS DE INDEXAÇÃO: Sistema urinário, fêmeas, porquinhos-daíndia, Cavia porcellus, embriologia, metanefros, modelos experimentais, roedores.

\section{INTRODUCTION}

The guinea pig is a hystricomorph rodent widely used as a model for researches related to reproduction and developmental biology (Stockard \& Papanicolau 1919, Evans \& Sack 1973, Miglino et al. 2004, Mess 2007, Oliveira et al. 2012, Vale et al. 2013, Silva et al. 2016). Clemons \& Seeman (2011) described several aspects of the usefulness of the species as an experimental model. Regarding the anatomy of the species, Cooper \& Schiller (1975) described the details in adults; however there is a lack of more detailed data on the urogenital apparatus of the female. On embryology, Evans \& Sack (1973) described events of embryonic development, however, development of urinary and genital organs were not object of detailed study. The species is also used as pet and its pregnancy lasts about 65-68 days (Banks et al. 2010).

The urinary tract is responsible for essential functions during postnatal life. The kidneys regulate secretion of nitrogenous products, water homeostasis, electrolyte and acid-base balance, in addition to the production of hormones. The lower urinary tract regulates pressure, urine storage, and urination (Cuckow et al. 2001). The urinary organs still present many knowledge gaps, especially regarding tissue differentiation of the kidneys, after the establishment of metanephros and the formation of glomeruli and their fenestrated capillaries (Satchell \& Braet 2009). Other information that needs further details is those related to the origin and formation of clitoral (in some cases partially clitoral) urethra in some females of mammals. Hyenas (Crocuta crocuta) were studied in the antiquity by Aristotle and continue to be studied because of the apparent masculinization of the external genitalia as demonstrated by complete channeling of the urethra in the hypertrophied clitoris of females (Yalcinkaya et al. 1993, Glickman et al. 2006, Cunha et al. 2014). The presence of a urethral ostium at the top of the clitoris in guinea pig was first described by Stockard \& Papanicolau (1919). However the anatomy of the urinary organs of the species was not the main focus of the authors' study.

A peniform clitoris and a possible intersexuality were described in moles (Talpa europaea) (Mathews 1935). Recently, Sinclair et al. (2016) discussed the use of anatomical terminology in this type of appendage of the external genitalia in some species of mammals. For example mice and rats develop a baculum in the external genitalia, composed of bone tissue and a urethral channel to both males and females, with some minor differences (Yang et al. 2010, Weiss et al. 2012, Schlomer et al. 2013, Cunha et al. 2015, Ipulan et al. 2016). In Spix cavies (Galea spixii), a species phylogenetically close to the guinea pig, the tissue processes involved in the formation of the partial clitoral urethra and the urethral meatus enclosed by preputial tissue in adult females (Santos et al. 2014a, 2014b) and subsequently during intrauterine development (Santos et al. 2014c, 2018) have been defined and established.

The macroscopic process of differentiation of the external genitalia in females during embryonic development was previously established in guinea pig (Santos et al. 2016a). However the microscopic aspects and chronology of the development of the clitoral urethra were not demonstrated. Based on the importance of guinea pigs as experimental models, we developed for the first time, a study that demonstrates the process of formation and differentiation of the urinary organs of the species in the prenatal period providing data for the comparative anatomy in mammals.

\section{MATERIALS AND METHODS}

Animals. Sixteen guinea pig concepts at 25, 30, 45 and $>65$ (65-68) days of gestation (DG) ( $n=4$ females per gestational period) were used. These females came from the pregnancies of 9 adult females, which were paired with 3 adult males. The study and methodology employed were duly authorized by the Bioethics Committee of the "Faculdade de Medicina Veterinária e Zootecnia" of the "Universidade de São Paulo" (Process number: 2521/2012).

Collection of conceptuses. Adult females were matched with adult males and daily monitoring of the copulation of the animals was performed by the exfoliative vaginal cytology method. Copulation was confirmed by light microscopy, through the presence of spermatozoa in the vaginal smear, in the samples transferred to microscopic slides and stained by the rapid-panoptic method. The time of detection of spermatozoa in the vaginal smear was determined as day 0 of gestation and then the time required to collect the embryos and fetuses at designated gestational ages was waited. When the corresponding gestational age reached the above-mentioned ages, the pregnant were pre-anesthetized with xylazine hydrochloride $2 \%(40 \mathrm{mg} / \mathrm{kg} / \mathrm{IM})$ and ketamine hydrochloride $1 \%(60 \mathrm{mg} / \mathrm{kg} / \mathrm{IM})$ and submitted to euthanasia by the administration of $2.5 \%$ sodium thiopental (60mg/kg/IV).

Dissections and macroscopic analysis. After euthanasia the females were dissected, and the embryos and fetuses were extracted from the uterus. After the female concepts were dissected, and the 
urinary organs were exposed and extracted. The kidneys (left and right) of each specimen were measured using precision caliper and weighed on a precision scale. Macroscopic photo documentation was performed using Olympus SP 810UZ 14mp digital camera. Quantitative data were subjected to analysis of variance using the GraphPad InStat program and means and standard deviations were calculated. The Cramer-von Mises test for normality was used to evaluate homoscedasticity between or among variables; the Tukey comparison average test was used to assess biometric rates. Variables are unstable $(\mathrm{CV} \leq 15 \%)$ at significance $\mathrm{p}<0.05$.

Light microscopy. Tissue samples were collected from the female urinary organs in each gestational age. The samples were fixed in $10 \%$ formalin solution and then dehydrated in a series of ethanol in increasing concentrations (from 50\% to 100\%). Then, samples were diaphanized in xylol, for later inclusion in paraffin. Cuttings of the $5 \mu \mathrm{m}$ thick from paraffin blocks were obtained in Leica RM 2155 microtome, which were stained in hematoxylin and eosin (HE). The microscopic photodocumentation was performed in an Olympus BX61VS photomicroscope. The concepts at the beginning of development ( 25 days) were included whole and cut respecting the following method: a cut of $5 \mu \mathrm{m}$ was used and four cuts of $5 \mu \mathrm{m}$ were discarded serially until the metanephros was found in the sample.

\section{RESULTS}

\section{Macroscopic analysis}

A pair of asymmetrical (right and left) kidneys with oval-shaped and lobate-shaped appearance kidneys was observed after 30 DG. The kidneys were in the abdominal cavity partially covered by a capsule of adipose tissue. The right kidney was positioned more cranially than the left one. Both kidneys (right and left) were associated medially with the respective adrenal glands (right and left) and the caudal vena cava. The right kidney was positioned dorsocaudally to the liver while the left kidney was positioned dorsocaudally to the greater curvature of the stomach. Each kidney had a cranial and a caudal pole, a ventral and a dorsal surface, and the medially positioned hilum, where the renal artery and vein and the ureter could be found. Left kidneys presented greater dimensions and weight when compared to right kidneys, but no statistical differences were found ( $p>0.05$ ) (Table 1 ). Internally two distinct regions: cortical and medullary, in addition to the renal pelvis, positioned medially were visualized. The ureters extended caudally until they reached the urinary vesicle. The urinary vesicle had a triangular shape from 30 to 45 DG and became oval after $>65$ DG. The pelvic urethra continued with the urinary vesicle and was partially channeled into the clitoris (forming a urethral meatus) until it reached its external ostium at the top of the organ after 65 DG. From 30 to 45 DG, the preputial tissue of the clitoris, initially flattened, curved caudally, forming a urethral meatus (Fig.1).

\section{Microscopic analysis}

Kidneys. During intrauterine development the metanephros was circumcised by a well apparent capsule composed of dense connective tissue at 25 DG and 30 DG. After 25 DG collecting tubules were present in the cortex and medulla. After 30 DG the organ begins to differentiate into the medulla and cortex to form the kidney. The renal hilum could be found from 30 DG. Vascular structures were present in this region. The renal pelvis arose at 30 DG. It was characterized by an epithelium that varied between three types at 45 DG: prismatic pseudostratified epithelium, cylindrical pseudostratified epithelium and transitional epithelium. It had a loose connective tissue layer of the submucosa. Beneath in the mucosa were collecting tubules, segments of the nephron and vascular structures. After $30 \mathrm{DG}$, the medullary zone had segments of proximal and distal convoluted tubules and the collecting ducts. The cortical zone consisted of the efferent and afferent arteries, glomeruli and proximal and distal convoluted tubules. At 25 DG, only a cluster of precursor glomerular cells within the renal interstitium was identified. After formation of the glomerulus at $30 \mathrm{DG}$, the glomerular unit organized to form a glomerular capsule and a visible urinary space after 45 DG (Fig.2).

Ureter. At $30 \mathrm{DG}$, it was possible to observe a distinction between tunics (mucosa and lamina propria of the mucosa, muscular and adventitia). At $30 \mathrm{DG}$, the muscular layer had no characteristic muscular fibers and the submucosa had loose connective tissue. The inner lining was defined by transitional epithelium formed by several layers of cells. Its innermost surface had a plasma membrane with the presence of globular surface cells, which are responsible for forming the osmotic barrier that prevents the communication between the urine and the cellular fluids of the epithelium. It also had intermediate cells and finally the basal cells, evidenced as the smallest cells because they have a small cytoplasm, being found near the basal compartment of the luminal transitional epithelium.

At 45 DG, the histological constitution of the tunics (mucosa, lamina propria of the mucosa, muscular and adventitia) became more differentiated. It was possible to observe the lamina propria with not modeled dense connective tissue; the thickening of the muscular tunica; and, the narrowing of the adventitia. After 65 DG the tissue differentiation was even more noticeable. At this stage, the connective tissue of the lamina propria was richly vascularized. In the lower ages, connective tissue was found with little vascularization, leading to the assumption that the need for blood irrigation becomes more prominent accompanying the development of the organ. The tunica adventitia, being the outermost tunic, was in contact with the abdominal cavity and adjacent structures, such as blood vessels (Fig.3).

Table 1. Measurements of guinea pig kidneys

\begin{tabular}{|c|c|c|c|c|c|c|}
\hline \multirow{2}{*}{ Measurement } & \multicolumn{3}{|c|}{ Right kidneys (Mean+SD) } & \multicolumn{3}{|c|}{ Left kidneys (Mean+SD) } \\
\hline & $30 \mathrm{DG}$ & $45 \mathrm{DG}$ & $>65 \mathrm{DG}$ & $30 \mathrm{DG}$ & $45 \mathrm{DG}$ & $>65 \mathrm{DG}$ \\
\hline Weight (g) & $0.33 \pm 0.03$ & $0.67 \pm 0.02$ & $1.19 \pm 0.02$ & $0.33 \pm 0.03$ & $0.69 \pm 0.03$ & $1.23 \pm 0.03$ \\
\hline Length (mm) & $0.47 \pm 0.02$ & $0.78 \pm 0.04$ & $1.02 \pm 0.05$ & $0.47 \pm 0.04$ & $0.81 \pm 0.04$ & $1.04 \pm 0.03$ \\
\hline Width (mm) & $0.27 \pm 0.02$ & $0.42 \pm 0.02$ & $0.49 \pm 0.01$ & $0.31 \pm 0.03$ & $0.43 \pm 0.03$ & $0.51 \pm 0.02$ \\
\hline Thickness (mm) & $0.24 \pm 0.03$ & $0.39 \pm 0.01$ & $0.48 \pm 0.03$ & $0.25 \pm 0.03$ & $0.42 \pm 0.03$ & $0.50 \pm 0.03$ \\
\hline
\end{tabular}




\section{DG}
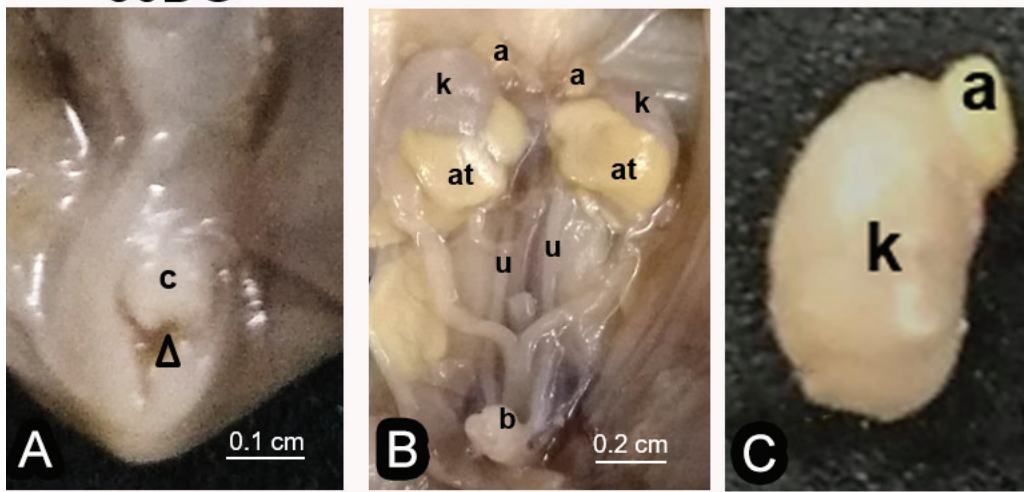

\section{$0.2 \mathrm{~cm}$}
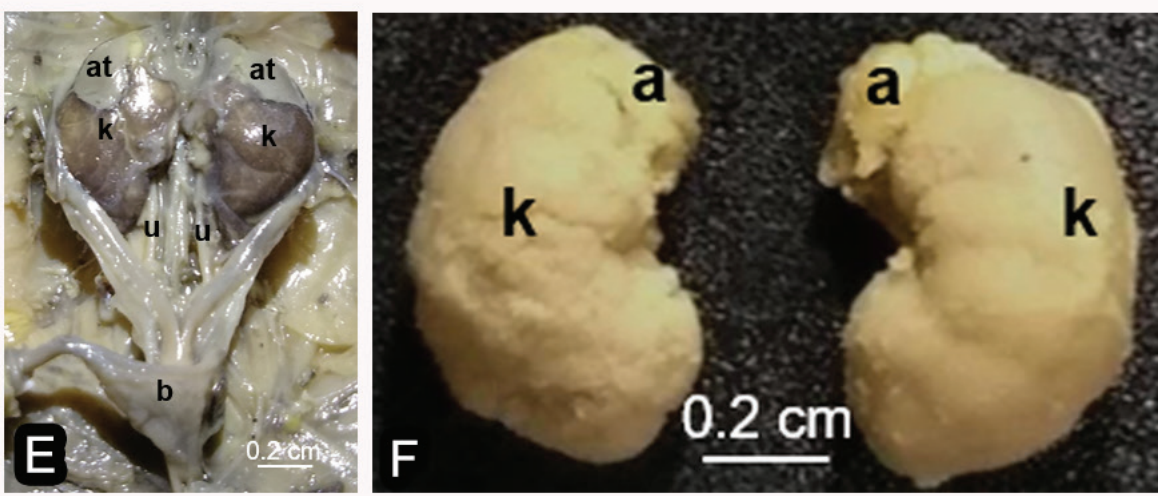

65DG
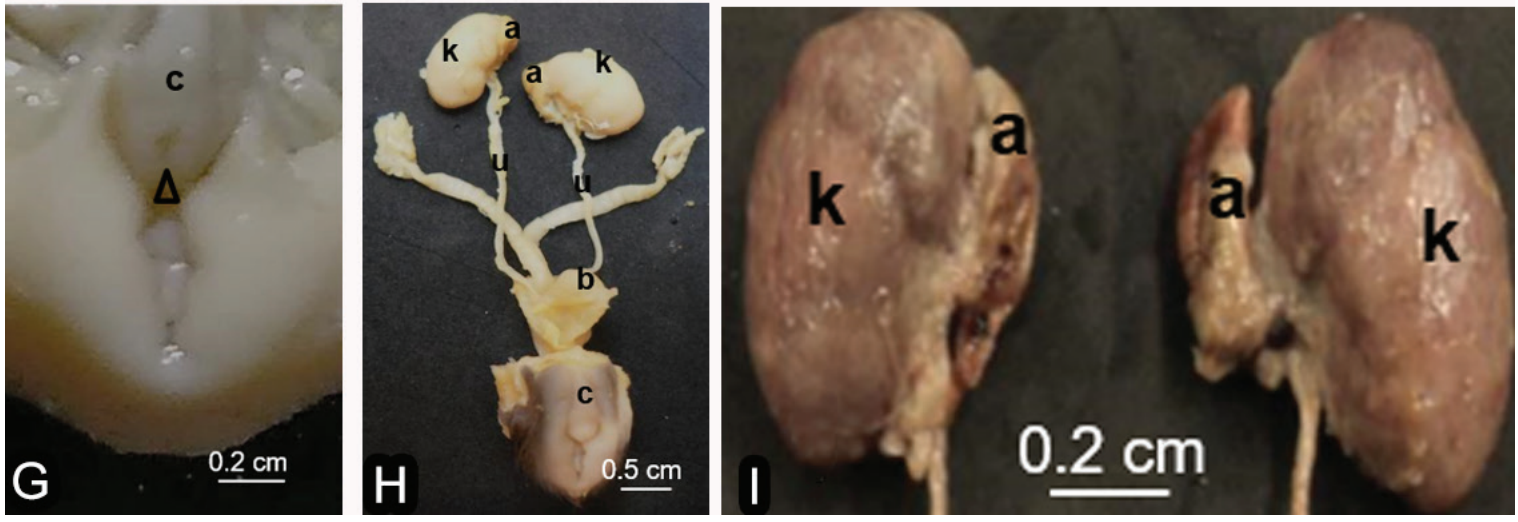

Fig.1. (A-C) Urinary organs development at 30 DG, (D-F) 45 DG and (G-I) >65 DG.

Urinary vesicle. The urinary vesicle presented histological characteristics like the ureter. Transitional epithelium composed of several layers of cells was present from the 30 DG until the end of gestation. The lamina propria of the mucosa formed the tunica submucosa, constituted by loose connective tissue and blood vessels, to later locate a layer of muscular tissue. The loose connective tissue of the submucosa present at 30 and 45 DG became not modeled dense connective tissue after 65 DG. The rich muscular layer increased its complexity and after the $45 \mathrm{DG}$ could be observed muscular fibers longitudinally and circularly arranged. Externally, the adventitia had mesothelium with pavement cells (Fig.4).

Urethra. The urethra could be divided into two parts, a pelvic and a clitoral urethra. Clitoral urethra was characterized by a urinary channel that partially pierced the clitoris and formed a urethral meatus surrounded by preputial tissue. The pelvic portion had internal lining epithelium composing the mucosa, followed by the submucosa composed of loose connective tissue, a muscular layer and the adventitia. The mucosa was composed by transitional epithelium. The connective tissue of the submucosa at $30 \mathrm{GD}$ was of the loose type. At $45 \mathrm{DG}$ there were regions composed of loose tissue and others composed of not modeled dense connective tissue. After the 65 DG, the connective tissue became only of the not modeled dense type with the presence of vascular elements. The muscular layer was composed of slightly defined smooth muscle between the 30 and 45 DG. After 65 DG, a rich musculature arranged with longitudinal and circular muscle bundles could be observed. The adventitial tunica that externally coated the organ was associated with the presence of blood vessels (Fig.5). 

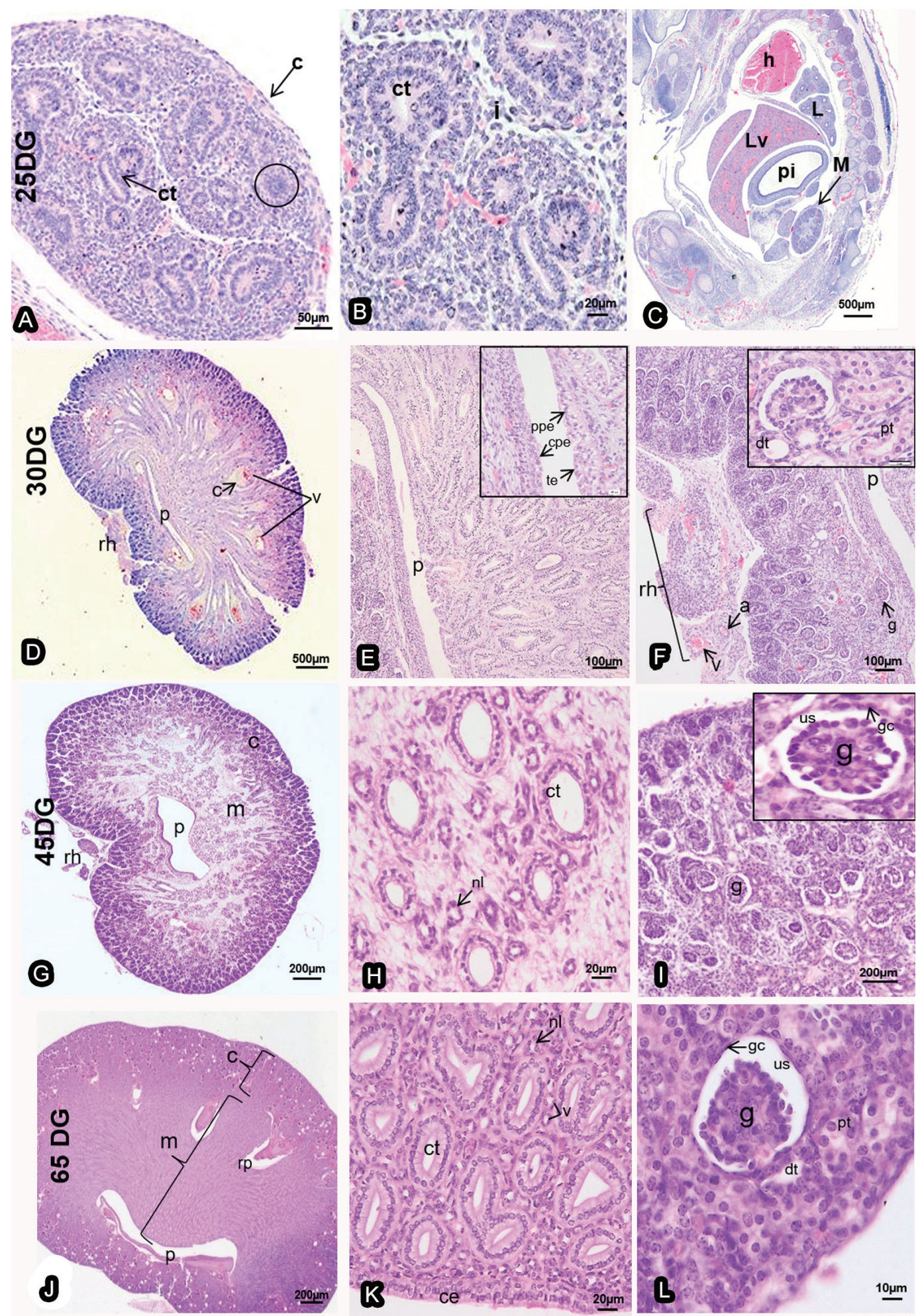

Fig.2. Development of the metanephros at (A-C) 25 DG and (D-F) of the kidneys at 30 DG, (G-I) 45 DG and (J-L) >65 DG. (A) Connective tissue capsule (c), collecting tubules (ct), precursor glomerular cells (circle). HE, bar $=50 \mu \mathrm{m}$. (B) Renal interstitium (i), collecting tubules (ct). HE, bar $=20 \mu \mathrm{m}$. (C) Metanephros (M), primitive intestine (pi), liver (Lv), lung (L), heart (h). HE, bar = 500 $\mu \mathrm{m}$. (D) Renal hilum (rh), pelvis (p), minor calyx (c), vessels (v). HE, bar $=500 \mu \mathrm{m}$. (E) Prismatic pseudostratified epithelium (ppe), cylindrical pseudostratified epithelium (cpe), transitional epithelium (te), renal pelvis (p). HE, bar =100 $\mathrm{m}$. (F) Renal hilum (rh), vein (v), artery (a), glomerulus (g), distal (dt) and proximal (pt) convoluted tubule. HE, bar $=100 \mu \mathrm{m}$. (G) Renal hilum (rh), pelvis (p), medulla (m), cortex (c). HE, bar $=200 \mu \mathrm{m}$. (H) Collecting tubules (ct), tubular segment of the nephron (nl). HE, bar $=20 \mu \mathrm{m}$. (I) Glomerulus (g), urinary space (us), glomerular capsule (gc). HE, bar $=200 \mu \mathrm{m}$. (J) Cortex (c), medulla (m), renal papilla (rp), pelvis (p). HE, bar $=200 \mu \mathrm{m}$. $(\mathbf{K})$ Collecting tubules (ct), vessels (v), tubular segment of the nephron (nl), columnar epithelium (ce). HE, bar = 20 $\mu$ m. (L) Glomerulus (g), glomerular capsule (gc), urinary space (us), distal (dt) and proximal (pt) convoluted tubule. HE, bar $=10 \mu \mathrm{m}$ 

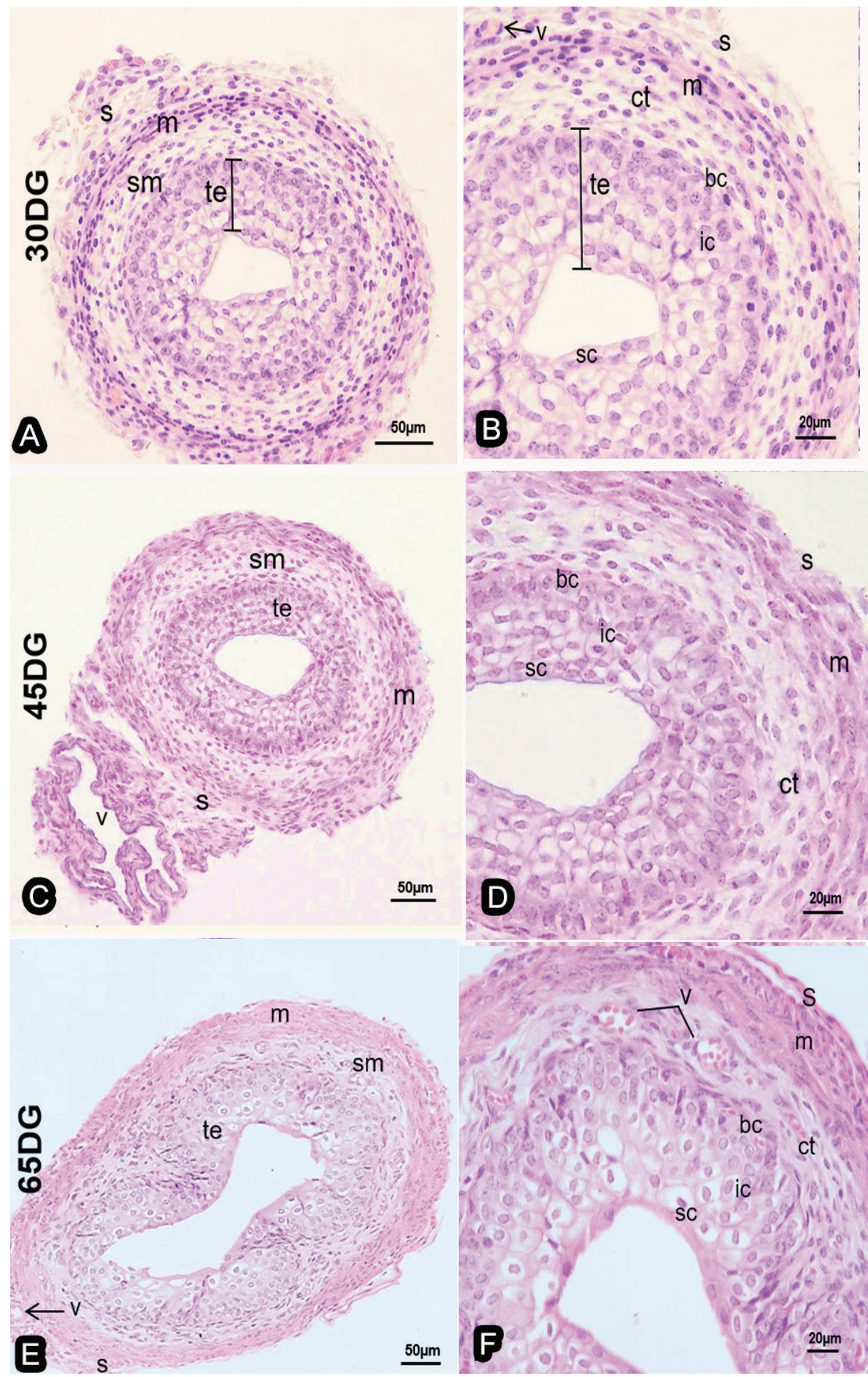

Fig.3. Development of the ureters at (A-B) 30 DG, (C-D) 45 DG and (E-F) >65 DG. (A) Adventitia (s), muscular layer (m), submucous (sm), transitional epithelium (te). HE, bar $=50 \mu \mathrm{m}$. (B) Blood vessels (v), adventitia (s), muscular layer (m), connective tissue (ct), transitional epithelium (te) with surface (sc), intermediate (ic) and basal cells (bc). HE, bar $=20 \mu \mathrm{m}$. (C) Submucous (sm), transitional epithelium (te), adventitia (s), muscular layer (m), blood vessels (v). HE, bar $=50 \mu \mathrm{m}$. (D) Transitional epithelium (te) with surface (sc), intermediate (ic) and basal cells (bc), adventitia (s), muscular layer (m), connective tissue (ct). HE, bar $=20 \mu \mathrm{m}$. (E) Muscular layer (m), submucous (sm), transitional epithelium (te), blood vessels (v), adventitia (s). HE, bar $=50 \mu \mathrm{m}$. (F) Blood vessels (v), adventitia (s), muscular layer (m), connective tissue (ct), transitional epithelium (te) with surface (sc), intermediate (ic) and basal cells (bc). HE, bar $=20 \mu \mathrm{m}$. 


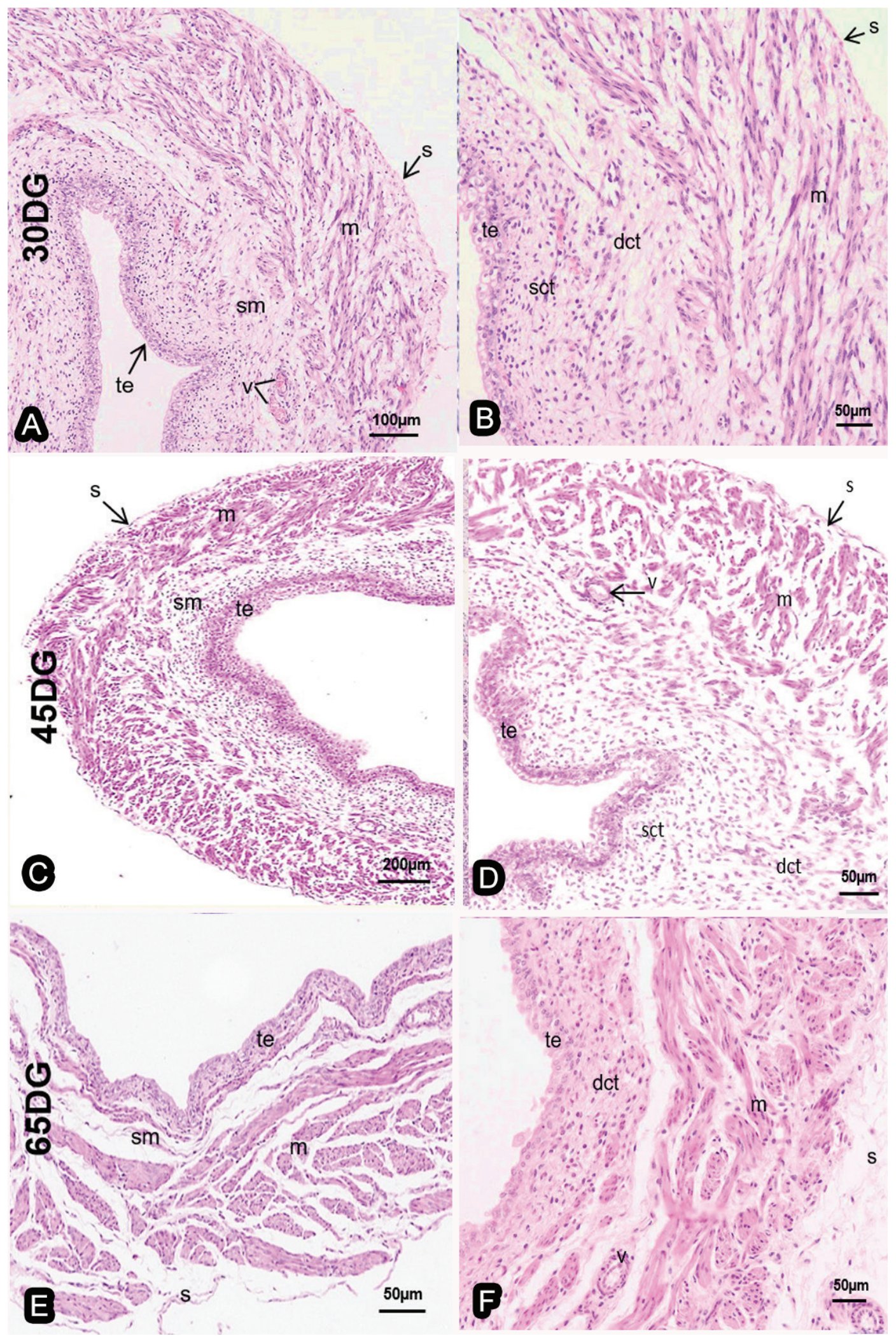

Fig.4. Development of the urinary vesicle at (A-B) 30 DG, (C-D) 45 DG and (E-F) >65 DG. (A) Adventitia (s), muscular layer (m), submucous $(\mathrm{sm})$, blood vessels (v), transitional epithelium (te). HE, bar $=100 \mu \mathrm{m}$. (B) Transitional epithelium (te), loose connective tissue (sct), not modeled dense connective tissue (dct), muscular layer (m), adventitia (s). HE, bar $=50 \mu \mathrm{m}$. (C) Adventitia (s), muscular layer (m), submucous (sm), transitional epithelium (te). HE, bar $=200 \mu \mathrm{m}$. (D) Transitional epithelium (te), blood vessels (v), muscular layer $(\mathrm{m})$, adventitia (s), loose connective tissue (sct), not modeled dense connective tissue (dct). HE, bar $=50 \mu \mathrm{m}$. (E) Submucous (sm), transitional epithelium (te), muscular layer (m), adventitia (s). HE, bar $=50 \mu \mathrm{m}$. (F) Transitional epithelium (te), not modeled dense connective tissue (dct), muscular layer (m), adventitia (s), blood vessels (v). HE, bar $=50 \mu \mathrm{m}$. 

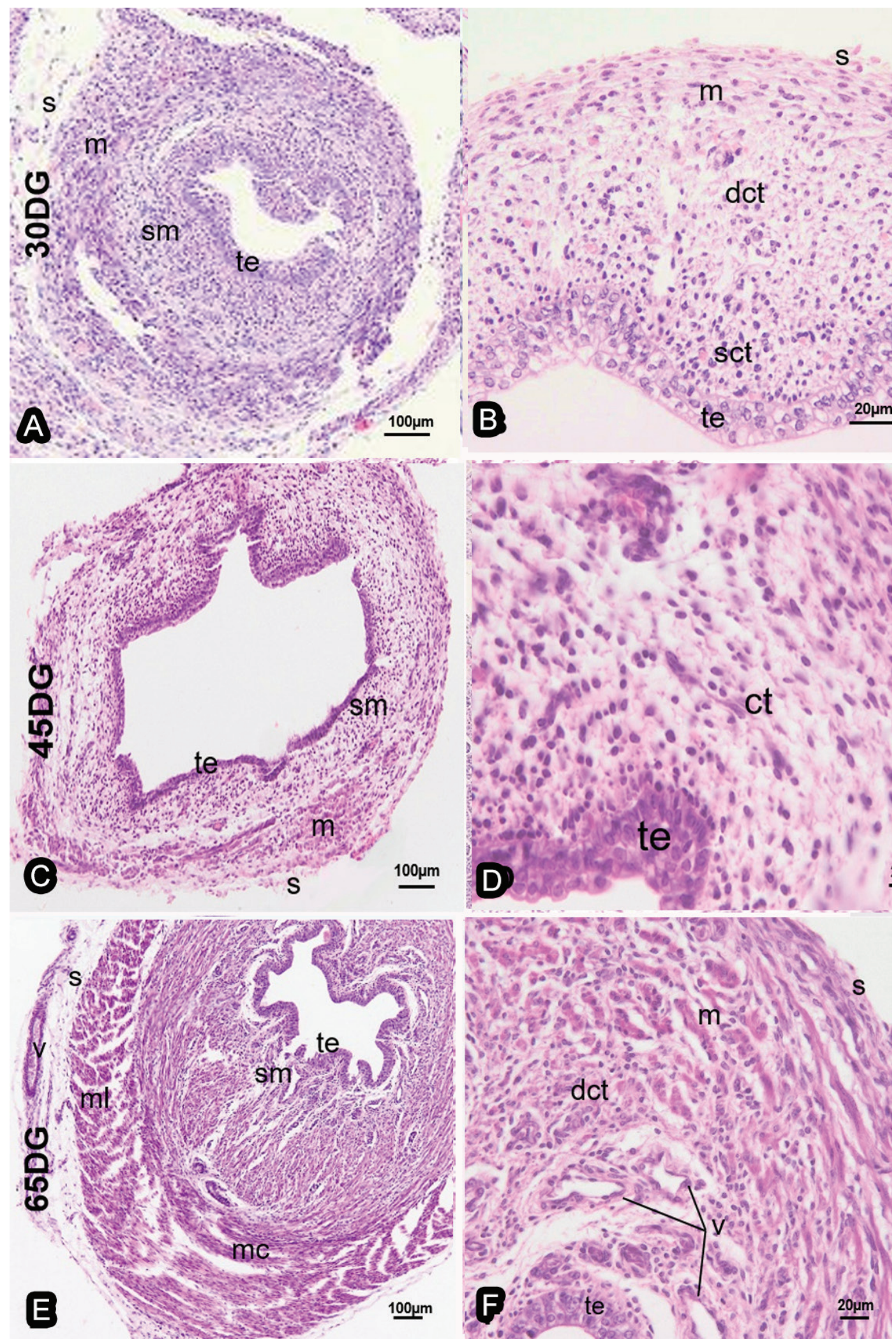

Fig.5. Development of the pelvic urethra at (A-B) 30 DG, (C-D) 45 DG and (E-F) >65 DG. (A) Adventitia (s), muscular layer (m), submucous $(\mathrm{sm})$, transitional epithelium (te). HE, bar $=100 \mu \mathrm{m}$. (B) Adventitia (s), muscular layer (m), not modeled dense connective tissue (dct), loose connective tissue (sct), transitional epithelium (te). HE, bar $=20 \mu \mathrm{m}$. (C) Submucous (sm), transitional epithelium (te), muscular layer (m), adventitia (s). HE, bar $=100 \mu \mathrm{m}$. (D) Submucous (sm), muscular layer (m), collecting tubules (ct), transitional epithelium (te). HE, bar $=20 \mu \mathrm{m}$. (E) Adventitia (s), blood vessels (v), longitudinal muscular (ml), transitional epithelium (te), submucous (sm), circular muscular layer (mc) layer. HE, bar $=100 \mu \mathrm{m}$. (F) Adventitia (s), muscular layer (m), not modeled dense connective tissue (dct), blood vessels (v), transitional epithelium (te). HE, bar $=20 \mu \mathrm{m}$. 

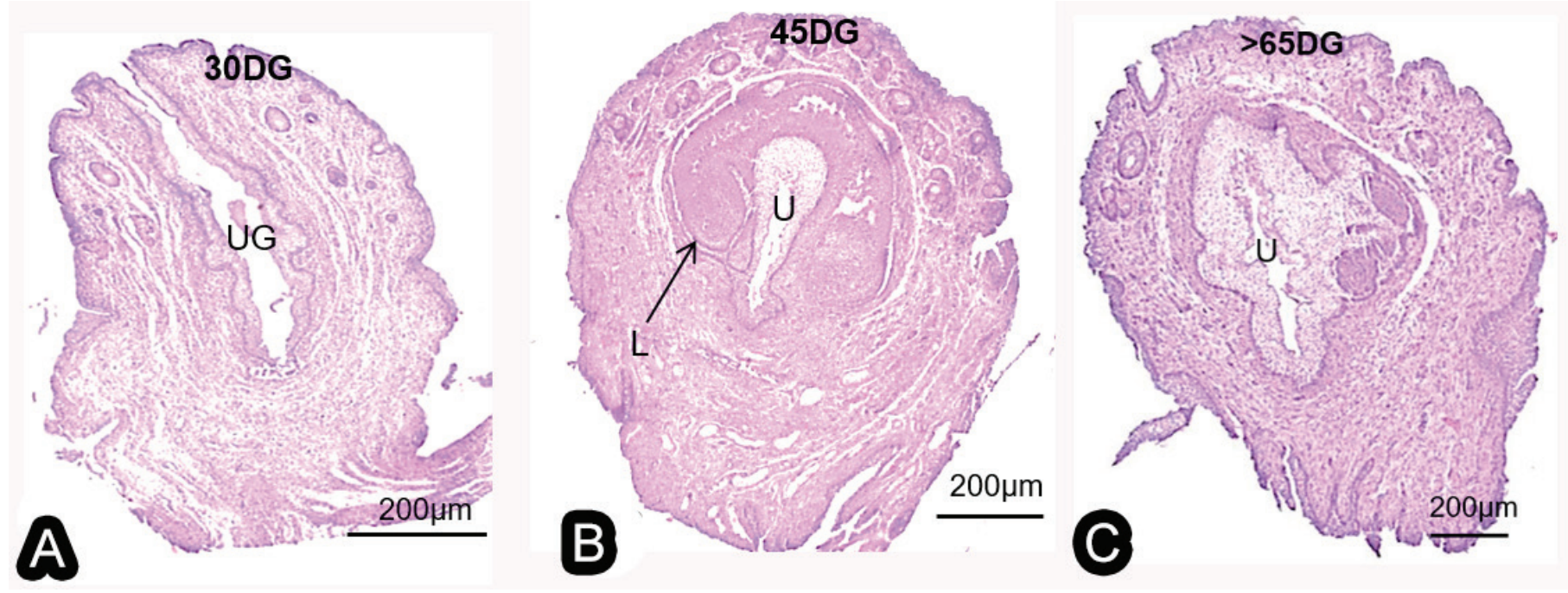

Fig.6. Development of the partial clitoral urethra and urethral meatus. (A) Approximation of the urethral folds and formation of the urethral sulcus (UG) at 30 DG. (B) Urethra (U) partially enclosed by clitoral tissue, delimited by the preputial lamina (L) at 45 DG. (C) Formation of the urethral meatus (U) enclosed by preputial tissue in the most distal portion of the organ after 65 DG. HE, bar $=200 \mu \mathrm{m}$.

In the clitoral portion, the urethral mucosa was lined by transitional epithelium from its base to the apex at all ages analyzed. At $30 \mathrm{DG}$ it was possible to observe the urethral plaque and the urethral sulcus without fusion of the urethral folds. At 45DG, with the fusion of the urethral folds, a urethral channel formed, being partially enclosed by clitoral tissue, which could be delimited by the preputial lamina. The preputial tissue was characteristic of the epidermis, with the presence of sebaceous glands and hair follicles, besides the external epithelial lining. It was possible to verify that, during prenatal development, the urethral glands were not found. After the 65 DG, with the elongation of the organ, a urethral meatus formed, after the end of the clitoral tissue. This meatus was surrounded by preputial tissue and opened in an ostium on the top of the organ (Fig.6).

\section{DISCUSSION}

Knowledge of the normal development of the urinary tract contributes to the understanding and perception of morphological variations between different species or even developmental anomalies (Cuckow et al. 2001, Santos Junior et al. 2014). In the present study we found that the renal development of guinea pig females, still in the intrauterine environment, presents a rapid evolution from the $25 \mathrm{DG}$ until the end of gestation. From the $30 \mathrm{DG}$, the renal and conductive anatomy already had the microstructural components like that described in adults (Cooper \& Schiller 1975). One detail is that the tunics have undergone tissue differentiation until the end of gestation. Highlight occurred for the fusion of the urethral folds in the genital tubercle, partially channeling the urethra into the clitoris and for the formation of a urethral meatus after the end of the clitoral tissue to open at the top of the organ. Our results demonstrated that the development of the urinary organs of the guinea pig females follow the pattern described in humans (Cuckow et al. 2001, Moore \& Persaud 2008) and domestic mammals (Sinowatz 2010), except for the presence of the partially channeled urethra into the clitoris.
Chronologically the development of urinary organs in mammals involves three steps: 1) Formation and degeneration of rudimentary pronephros; 2) formation of the mesonephros which has glomerular corpuscles and degenerate completely in females, in males this transitory organ is established and modifies to form the epididymis, stimulated by androgenic hormones; 3) finally the metanephro, which originates from the ureteric bud to form the true kidney (Cuckow et al. 2001, Santos Junior et al. 2014). We did not aim to study the pronephro and mesonephro phases. In our study as described in other mammals (Cuckow et al. 2001, Sinowatz 2010), after the formation and establishment of the metanephros, these organs begin to increase their complexity with the formation of the renal pelvis and the branch of the collector ducts and by the presence of convoluted tubules. Glomeruli and portions of convoluted tubules are present in the cortex. The glomeruli begin to form in the metanephros after $25 \mathrm{DG}$ by the presence of clusters of precursor glomerular cells and at $45 \mathrm{DG}$ already have well defined urinary space and glomerular capsule in guinea pigs. In general, the conductive and excretory pathways of the urinary system, except for the clitoral urethra, have a similar histological conformation. That's they have mucosa with transitional epithelium and a lamina propria in the ureter, which forms a tunica submucosa in the other organs. This lamina is formed by connective tissue that passes from loose in the initial periods to not model dense in the final stages of gestation. They have a muscular layer not very evident in the initial stage of development, but that modifies forming a layer with fibers arranged circularly and longitudinally to the end of the gestation. Finally, they have an outer coating, composed of the mesothelium of the adventitial tunica, which presents blood vessels and is related to organs and structures of the abdominal cavity.

An emphasis should be given to the development of partially channeled urethra of the clitoris in the present study. This is a case where the urinary organs are closely associated with genital organs of female. This conformation 
has also been investigated in other rodents of the Caviidae family, such as Spix cavies. In Spix cavies, Santos et al. (2018) demonstrated the process of fusion of the urethral folds forming a urethra, partially enclosed by the clitoral tissue. Similar to our results the urethral channeling is never complete by the clitoris; however, a urethral meatus forms after the end of the clitoral tissue and continues until it opens into an external ostium at the top of the organ. The structure that allows this morphological adaptation is a dense and fixed prepuce that continues to coat the entire clitoris like a cap, which guarantees the appearance of masculinized and hypertrophied genitalia. However through the study in Spix cavies (Santos et al. 2018) and now in the guinea pigs unlike what was thought this apparent hypertrophied clitoris channeled by the urethra is formed by preputial tissue, forming an appendix, channeled by a urethral meatus. This urethral meatus is formed after the end of the partially clitoral urethra to give continuity to the urinary channel and allow urine output to the outside.

In some rodents of the Caviidae family such as Galea musteloides, Cavia aperea (Touma et al. 2001), Galea spixii (Santos et al. 2016b), besides the guinea pig itself (Stockard \& Papanicolau 1919, Kelly \& Papanicolaou 1927), females are characterized by the formation of the vaginal closure membrane, which occludes the external vaginal ostium and part of the vulva from birth to puberty; during part of the estrous cycle, except in estrus and throughout gestation. This fact may help to explain the anatomical adaptation found since the formation of the vaginal closure membrane, external urethral ostium would be obstructed, preventing urine output to the outside. The deviation of the urethra partially to the clitoris and the formation of a preputial appendix channeled through a urethral meatus opening at the top of the organ guarantees urine output even when the vaginal closure membrane is present. It appears that this conformation follows some processes that resemble that described during the formation of the urethra in mice females, except for bone tissue that occurs in mice, but does not occur in guinea pigs (Rodriguez Junior et al. 2012, Ipulan et al. 2016). On the other hand, complete fusion of the urethra into the clitoris occurs in hyenas (Glickman et al. 2006). In hyenas this fusion resembles the process that occurs in the penis in males of the same species, which in turn resembles that described in other male mammals. In men the urethra channels the genital tubercle by the fusion of the urethral folds, being totally enveloped by the preputial lamina. In addition, another fusion occurs with the preputial tissue and suggests the "Double Zipper Hypothesis". In fact the urethra is completely channeled into the penis ( $\mathrm{Li}$ et al. 2015). This fact did not occur with guinea pig females of the present study or even in Spix cavies (Santos et al. 2018) and members of Dasyproctidae family such as Dasyprocta leporina (Oliveira et al. 2017). In these species occur only the fusion of the urethral folds in the prepuce to form the urethral meatus.

The anatomical conformation of the partial clitoral urethra in guinea pigs may be better explored in future studies. A study of organ ontogeny from the formation of the undifferentiated tubercle and using specimens at shorter intervals of development could reveal more details of the morphological characterization and the adaptations necessary for the formation of the partially channeled urethra in the clitoris and the formation of the urethral meatus on the prepuce. Other studies could explore the influence of sex steroid hormones (Rodriguez Junior et al. 2012, Ipulan et al. 2016) and their respective receptors during development (Yang et al. 2010) as successfully preformed in mice. We believe that guinea pigs may be useful because they have a longer gestational period than mice and rats, which would allow extracting more details of the morphological events during the formation of the urinary organs, allowing comparisons with other mammals. It could also be useful to improve the understanding of changes resulting from malformations of these organs.

In summary the urinary organs of the species at 25 DG are constituted by metanephros, where collecting ducts and glomerular precursor cells are present. After this period metanephro undergoes microstructural modifications to form the kidneys until the end of the prenatal period, when they are divided into: cortex, where the glomeruli and proximal segments of the nephron are present; and the medulla, where distal segments of the nephron, collecting ducts, and pelvis are present. The pelvis of each kidney is drained by the ureters. The ureters also undergo tissue differentiation until the end of the prenatal period to form their differentiated tunics (mucosa with transitional epithelium and lamina propria, muscular, and adventitia). These open into the urinary vesicle. The urinary vesicle also undergoes tissue changes to form the tunics like those of the ureters, with emphasis on the lamina propria of the mucosa that becomes a tunica submucosa and due to the greater volume of the muscular tunica. The urinary vesicle is drained by the pelvic urethra, with its tunics: mucosa lined by transitional epithelium, submucosa, muscular and adventitia, which also undergo tissue differentiation. Finally, a partially clitoral urethra and a urethral meatus in the prepuce of the clitoris may also be found. This urethral channel begins to form with the appearance of the urethral plaque and the urethral groove at $30 \mathrm{DG}$ and thereafter with the fusion of the urethral folds to form a partially channeled urethra at the clitoris at 45 DG. At the end of the clitoral tissue in the most distal portion, a urethral meatus formed by the fusion of the prepuce may be observed. This meatus opens into an external ostium at the top of the organ after the 45 DG.

\section{CONCLUSIONS}

The development of female guinea pig permanent urinary organs begins with the appearance and maintenance of the metanephros which undergoes tissue differentiation as the organ develops. Initially the collecting ducts and glomeruli are scattered throughout the organ's parenchyma. As the organ develops the glomeruli proliferate and migrate to the cortex. Renal pelvis formation also occurs in the late stages of prenatal development. Initially these organs have loose connective tissue that is replaced by not modeled dense connective tissue in the late stages of prenatal development.

The differentiation of muscular tunics is also evident especially in the urinary vesicle, in the late stages of intrauterine development.

The females of this species also have a partial clitoral urethra, formed by the fusion of the urethral folds, which partially channel the urethra and form a urethral meatus which in turn opens outwards in the most distal portion of the clitoris.

Acknowledgements.- To Fapesp for the financial support to the first author (Process 2016/24040-0).

Conflict of interest statement.- The authors have no competing interests. 


\section{REFERENCES}

Banks R.E., Sharp J.M., Doss S.D. \& Vanderford D.A. 2010. Exotic Small Mammal Care and Husbandry. Wiley-Blackwell, Iowa. 180p.

Clemons D.J. \& Seeman J.L. 2011. The Laboratory Guinea Pig. 2nd ed. CRC Press, Boca Raton. 169p.

Cooper G. \& Schiller A.L. 1975. Anatomy of the Guinea pig. Harvard University Press, Cambridge. $417 \mathrm{p}$.

Cuckow P.M., Nyirady P. \& Winyard P.J.D. 2001. Normal and abnormal development of the urogenital tract. Prenatal Diagnosis 21(11):908-916. <http://dx.doi.org/10.1002/pd.214> <PMid:11746143>

Cunha G.R., Risbridger G., Wang H., Place N.J., Grumbach M., Cunha T.J., Weldele M., Conley A.J., Barcellos D., Agarwal S., Bhargava A., Drea C., Hammond G.L., Siiteri P., Coscia E.M., McPhaul M.J., Baskin L.S. \& Glickman S.E. 2014. Development of the external genitalia: perspectives from the spotted hyena (Crocuta crocuta). Differentiation 87(1):4-22. <http://dx.doi.org/10.1016/j. diff.2013.12.003 > <PMid:24582573>

Cunha G.R., Sinclair A., Risbridger G., Hutson J. \& Baskin L.S. 2015. Current understanding of hypospadias: relevance of animal models. Nature Revs Urol. 12(5):271-280. <http://dx.doi.org/10.1038/nrurol.2015.57> $<$ PMid:25850792>

Evans H.E. \& Sack W.O. 1973. Prenatal development of domestic and laboratory mammals: growth curves, external features and selected references. Anat. Histol. Embryol. 2(1):11-45. <http://dx.doi.org/10.1111/j.1439-0264.1973. tb00253.x> <PMid:4745140>

Glickman S.E., Cunha G.R., Drea C.M., Conley A.J. \& Place N.J. 2006. Mammalian sexual differentiation: lessons from the spotted hyena. Trends Endocrinol. Metabol. 17(9):349-356. <http://dx.doi.org/10.1016/j.tem.2006.09.005> <PMid:17010637>

Ipulan L.A., Raga D., Suzuki K., Murashima A., Matsumaru D., Cunha G. \& Yamada G. 2016. Investigation of sexual dimorphisms through mouse models and hormone/hormone-disruptor treatments. Differentiation 91(4/5):78-89. <http://dx.doi.org/10.1016/j.diff.2015.11.001> <PMid:26651426>

Kelly G.L. \& Papanicolaou G.N. 1927. The mechanism of the periodical opening and closing of the vaginal orifice in the guinea-pig. Am. J. Anat. 40(2):387411. <http://dx.doi.org/10.1002/aja.1000400209>

Li Y., Sinclair A., Cao M., Shen J., Choudhry S., Botta S., Cunha G. \& Baskin L. 2015. Canalization of the urethral plate precedes fusion of the urethral folds during male penile urethral development: the double zipper hypothesis. J. Urol. 193(4):1353-1360. <http://dx.doi.org/10.1016/j.juro.2014.09.108> <PMid:25286011>

Mathews L.H.1935. The oestrus cycle and intersexuality in the female mole (Talpa europaea, Linn). Proc. Zool. Soc. London 2:347-383.

Mess A. 2007. The guinea pig placenta: model of placental growth dynamics. Placenta 28(8/9):812-815.<http://dx.doi.org/10.1016/j.placenta.2007.02.005> <PMid:17382996>

Miglino M.A., Carter A.M., Ambrósio C.E., Bonatelli M., Oliveira M.F., Santos F., Rodrigues R.F. \& Santos T.C. 2004. Vascular organization of the histricomorph placenta: a comparative study in the agouti, capybara, guine pig, paca and rock cavy. Placenta 25(5):438-448. <http://dx.doi.org/10.1016/j. placenta.2003.11.002> <PMid:15081638>

Moore K. \& Persaud T.V.N. 2008. The Developing Human: clinically oriented embryology. 8th ed. Saunders Elsevier, Philadelphia. 560p.

Oliveira M.F., Vale A.M., Favaron P.O., Vasconcelos B.G., Oliveira G.B. \& Miglino M.A. 2012. Development of yolk sac inversion in Galea spixii and Cavia porcellus (Rodentia, Caviidade). Placenta 33(10):878-881. <http://dx.doi. org/10.1016/j.placenta.2012.06.019> <PMid:22809674>

Oliveira G.B., Araújo Júnior H.N., Silva Costa H., Silva A.R., Moura C.E.B., Oliveira Rocha H.A., Miglino M.A. \& Oliveira M.F. 2017. Post-implantation development of red-rumped agouti (Dasyprocta leporina Linnaeus,
1758). Anim. Reprod. Sci. 182(7):35-47. <http://dx.doi.org/10.1016/j anireprosci.2017.04.007><PMid:28502649>

Rodriguez Junior E., Weiss D.A., Ferretti M., Wang H., Menshenina J., Risbridger G., Handelsman D., Cunha G. \& Baskin L. 2012. Specific morphogenetic events in mouse external genitalia sex differentiation are responsive/ dependent upon androgens and/or estrogens. Differentiation 84(3):269279. <http://dx.doi.org/10.1016/j.diff.2012.07.003><PMid:22925506>

Santos A.C., Olio R.L., Viana D.C., Oliveira M.F., Miglino M.A. \& Assis-Neto A.C. 2014a. Morphological description of unusual urinary tract in the female of a rodent, Galea spixii (Wagler, 1831). Pakistan J. Zool. 46(6):1617-1623.

Santos A.C., Bertassoli B.M., Viana D.C., Vasconcelos B.G., Oliveira M.F., Miglino M.A. \& Assis-Neto A.C. 2014b. The morphology of female genitalia in Galea spixii (Caviidae, Caviinae). Biosci. J. 30(6):1793-1802.

Santos A.C., Oliveira M.F., Viana D.C. \& Assis Neto A.C. 2014c. Sexual differentiation of the external genitalia in embryos and fetuses in the spix's yellow-toothed cavy (Galea spixii). Placenta 35(9):A25. <http:// dx.doi.org/10.1016/j.placenta.2014.06.085>

Santos A.C., Favaron P.O., Viana D.C., Ferreira A.O., Silva F.M.O., Alcântara D., Vasconcelos B.G., Rici R.E.G., Assis Neto A.C. \& Miglino M.A. 2016 . Intrauterine development of female genital organs in Cavia porcellus (Rodentia, Caviidae). Pakistan J. Zool. 46(2):389-397.

Santos A.C., Oliveira G.B., Viana D.C., Oliveira F.D., Silva Rdos.S., Rici R.E., Oliveira M.F. \& Assis Neto A.C. 2016b. Development and morphological changes in the vaginal closure membrane throughout gestation in Galea spixii (Rodentia: Caviidae). Microsc. Res. Tech. 79(5):359-364. <http:// dx.doi.org/10.1002/jemt.22638><PMid:26873391>

Santos A.C., Conley A.J., Oliveira M.F. \& Assis Neto A.C. 2018. Development of urogenital system in the Spix cavy: a model for studies on sexual differentiation. Differentiation 101:25-38. <http://dx.doi.org/10.1016/j. diff.2018.04.001><PMid:29684807>

Santos Junior A.C.S., Miranda D.M. \& Silva A.C.S. 2014. Congenital anomalies of the kidney and urinary tract: an embryogenetic review. Birth Defects Res., C. 102(4):374-381.

Satchell S.C. \& Braet F. 2009. Glomerular endothelial cell fenestrations: an integral component of the glomerular filtration barrier. Am. J. Renal Physiol. 296(5):947-956. <http://dx.doi.org/10.1152/ajprenal.90601.2008> $<$ PMid:19129259>

Schlomer B.J., Feretti M., Rodriguez Junior E., Blaschko S., Cunha G. \& Baskin L. 2013. Sexual differentiation in the male and female mouse from days 0 to 21: a detailed and novel morphometric description. J. Urol. 190(Suppl.4):1610-1617. <http://dx.doi.org/10.1016/j.juro.2013.02.3198> <PMid:23473905>

Silva F.M.O., Alcantara D., Carvalho R.C., Favaron P.O., Santos A.C., Viana D.C \& Miglino M.A. 2016. Development of the central nervous system in guinea pig (Cavia porcellus, Rodentia, Caviidae). Pesq. Vet. Bras. 36(8):753-760. <http://dx.doi.org/10.1590/S0100-736X2016000800013>

Sinclair A.W., Glickman S.E., Baskin L. \& Cunha G.R. 2016. Anatomy of mole external genitalia: setting the record straight. Anat. Rec. 299(3):385-399. <http://dx.doi.org/10.1002/ar.23309><PMid:26694958>

Sinowatz F. 2010. Development of the urogenital system, p.252-283. In: Hyttel P., Sinowatz F. \& Vejlsted M. (Eds), Essential of Domestic Animal Embryology. Saunders Elsevier, Edinburgh, London.

Stockard C.R. \& Papanicolau G.N. 1919. The vaginal closure membrane copulation and the vaginal plug in the guinea pig, with further considerations of the oestrous rhytm. Biol. Bull. 37(4):222-244.<http:// dx.doi.org/10.2307/1536207>

Touma C., Palme R. \& Sachser N. 2001. Different types of oestrous cycle in two closely related South American rodents (Cavia aperea and Galea musteloides) with different social and mating systems. Reproduction 121(5):791-801. <http://dx.doi.org/10.1530/rep.0.1210791><PMid:11427168> 
Vale A.M., Oliveira G.B., Favaron P.O., Miglino M.A., Paula V.V., Silva A.R. \& Oliveira M.F. 2013. Dinâmica da inversão do saco vitelino em preás (Galea spixii Wagler, 1831). Pesq. Vet. Bras. 33(8):1033-1040. <http://dx.doi. org/10.1590/S0100-736X2013000800014>

Weiss D.A., Rodriguez Junior E., Cunha T., Menshenina J., Barcellos D., Chan L.Y., Risbridger G., Baskin L. \& Cunha G. 2012. Morphology of the external genitalia of the adult male and female mice as an endpoint of sex differentiation. Mol. Cell. Endocrinol. 354(1/2):94-102. <http://dx.doi. org/10.1016/j.mce.2011.08.009> <PMid:21893161>
Yang J.H., Menshenina J., Cunha G.R., Place N. \& Baskin L.S. 2010. Morphology of mouse external genitalia: implications for a role of estrogen in sexual dimorphism of the mouse genital tubercle. J. Urol. 184(4 Suppl.):1604-1609. <http://dx.doi.org/10.1016/j. juro.2010.03.079><PMid:20728117>

Yalcinkaya T.M., Siiteri P.K., Vigne J.L., Licht P., Pavgi S., Frank L.G. \& Glickman S.E. 1993. A Mechanism for virilization of female spotted hyenas in utero. Science 260(5116):1929-1931. <http://dx.doi.org/10.1126/ science.8391165><PMid:8391165> 